\title{
Hubungan antara Self Management dengan Perilaku Agresi pada Siswa SMA
}

\author{
Risqi Dwi Amaliasari ${ }^{1}$, Uun Zulfiana ${ }^{2}$ \\ Fakultas Psikologi, Universitas Muhammadiyah Malang \\ e-mail : 'risqiamalia84@gmail.com
}

\begin{abstract}
Aggression behavior among high school students or teenagers is still often found, for example: brawls, bullying. A person will behave aggressively so he will think first in acting so that he is able to manage himself (self management). The purpose of the study was to determine the relationship between self management and aggression behavior in high school students. This study uses a quantitative non-experimental approach. The subjects were 217 students of class X and XI SMA taken by stratified sampling technique. The research instrument uses the scale of aggression behavior and self management scale. The method of data analysis was the product moment correlation. Data analysis was carried out with the help of SPSS version 22.0. The results showed a value ( $r$ ) of -0.122 with $p$ was $0.037<0.05$. This shows that there is a significant negative relationship between self management and aggression behavior in high school students. The contribution of self management to aggression behavior is $1,5 \%\left(r^{\wedge} 2=0.015\right)$.
\end{abstract}

\section{KEYWORDS Self Management, Aggression Behavior, High School Students}

CITATION Amaliasari, D., A. \& Zulfiana, U. (2019). Hubungan antara self management dengan perilaku agresi pada siswa SMA. Cognicia, 7, (3), 308-320.

Remaja seringkali dikenal dengan proses pencarian identitas diri, dimana mereka ingin menemukan dan menunjukkan siapa dirinya agar mendapatkan pengakuan dari teman-teman dan lingkungan sosialnya. Perubahan kognitif meliputi perubahan dalam berfikir, intelegensi dan bahasa tubuh, sedangkan perubahan sosial-emosional meliputi perubahan dalam hubungan interpersonal baik keluarga maupun lingkungan sekitar. Masa remaja dikenal sebagai masa dimana penuh masalah. Kesulitan yang dihadapi oleh remaja dapat berpengaruh dalam tugas perkembangannya, dan remaja mempunyai tugas perkembangan yang harus dijalani menuju proses kedewasaan (Sarwono, 2005). Berbagai kesulitan yang dihadapi remaja dalam mencapai tugas perkembangan menyebabkan perkembangan emosi dan perilaku sosial menjadi terhambat, sehingga membuat para remaja melakukan perilaku agresi (Annisavitry, 2017).

Baron (2012) bahwa perilaku agresi dapat dilakukan secara fisik maupun mental, dengan demikian dapat dilihat dan diamati, karena memiliki bentuk yang jelas, yaitu bentuk fisik pukulan, tendangan, dan verbal (cacian, hujatan, makian). Perilaku agresi sering kali disebabkan oleh amarah yang merupakan jembatan psikologis antara komponen perilaku dan komponen kognitif dalam perilaku agresi. Individu pada umumnya menjadi lebih agresi ketika sedang marah dibandingkan saat tidak marah (Lickley, 2018). 
Bentuk-bentuk perilaku agresi fisik dianggap lebih kejam, sedangkan tindakan nonfisik seperti perilaku agresi verbal dianggap lebih normatif. Hal ini didukung oleh Farrell (2016) yang menemukan bahwa dibandingkan dengan perilaku agresi fisik, penilaian remaja tentang frekuensi perilaku agresi verbal mereka lebih dianggap dalam batas wajar dibandingkan remaja yang berperilaku melakukan perilaku agresi fisik. Azevedo (2018) juga menemukan bahwa terdapat kenakalan remaja yang melakukan perilaku agresi langsung yaitu, fisik dan verbal. Akibatnya hal yang terjadi ketika seseorang melakukan perilaku agresi yang dilakukan secara individu atau kelompok dapat mengakibatkan orang lain terluka serta merusak milik orang, menyerang seseorang, membunuh, atau menghukum orang lain. Dirks (2017) menyatakan bahwa perilaku agresi dilakukan secara dirancang. Perilaku agresi sering dilakukan seseorang unuk mengungkapkan perasaan dan menyelesaikan persoalan. Perilaku agresi terjadi dimana saja seperti perkelahian antar pelajar siswa SMA.

Komisi Perlindungan Anak Indonesia (KPAI) mencatat kasus di dunia pendidikan pada tanggal 30 Mei 2018 terdapat 161 kasus kekerasan. Terdapat 23 kasus atau 14,3\% anak menjadi korban tawuran, 31 kasus atau 19,3\% anak pelaku tawuran, 36 kasus atau 22,4\% anak korban kekerasan dan bullying, dan 41 kasus atau 25,5\% anak sebagai pelaku kekerasan serta bullying, sisanya 30 kasus atau 18,7\% anak korban kebijakan sekolah yang membuat siswa tidak dapat melanjutkan sekolah atau putus sekolah (Tempo.co, 2018). Berdasarkan data yang telah diberikan oleh komisi perlindungan anak Indonesia (KPAI) dapat diketahui kasus anak yang paling banyak adalah mengenai kekerasan dan bullying baik korban maupun pelaku. Faktor personal yang dimaksud merupakan sifat dasar atau bawaan. Korban dari perilaku agresi sering diperlakukan agresi oleh rekan-rekannya. Terdapat beberapa bentuk perilaku agresi secara fisik salah satunya adalah mendorong (Card \& Hodges, 2008). Bagi kaum muda di seluruh dunia, survei yang dilakukan pada perwakilan siswa SMA di 66 negara menunjukkan bahwa terdapat $32,1 \%$ responden melaporkan telah menjadi korban dalam dua bulan terakhir. Kebanyakan korban rata-rata pada usia masa remaja awal (Orpinas, 2001).

Penelitian Shelton (2017) menunjukkan bahwa terdapat $72,16 \%$ pelajar melakukan jenis kejahatan yang melibatkan kekerasan fisik, sedangkan sisanya 27,84\% siswa cenderung melakukan jenis kejahatan yang tidak melibatkan kekerasan fisik. Berdasarkan penelitian Routt \& Anderson (2018) menunjukkan bahwa dari keseluruhan remaja yang diwawancarai, $72 \%$ melakukan serangan fisik kepada ibu mereka, 16\% menyerang atau mengancam ayah mereka, 5\% karena menyerang atau mengancam kakak mereka, dan 5\% menyerang atau mengancam saudara mereka. Secara umum, faktor penyebab perilaku agresi dibedakan menjadi dua yaitu faktor personal dan sosial.

Penelitian pada remaja berdasarkan studi yang dilakukan oleh (Yuliani, 2013) bahwa anger (kemarahan) siswa di SMA Sungai Limau menunjukkan rasa marah sebesar 43,8\%. Dimana kemudian dapat memunculkan perilaku agresi. Agresi verbal mengumpat secara langsung atau mencaci maki baik secara langsung maupun melalui media sosial. Kemampuan kelola emosi merupakan kemampuan yang penting dimiliki oleh remaja. Individu yang memiliki kemampuan regulasi emosi atau kelola emosi, khususnya emosi marah dengan baik akan lebih mudah untuk berinteraksi sosial dan 
terampil dalam menyelesaikan konflik interpersonal. Dalam hal ini adalah perlunya memiliki keterampilan mengelola rasa marah merupakan kemampuan seseorang untuk mengendalikan rasa marahnya dan memberikan respon terhadap dengan cara yang dapat diterima oleh lingkungan sekitar.

Tindak kekerasan saat ini tidak hanya dilakukan oleh orang dewasa, siswa SMA dan bahkan anak-anak saat ini sudah banyak yang melakukan tindak kekerasan. Sebuah artikel menunjukkan fakta dan data sekitar 2.879 anak telah melakukan tindakan kekerasan dan harus berhadapan dengan hukum. Mulai dari rentang usia 612 tahun sebanyak 268 anak (9\%), serta anak berusia 16-18 tahun sebanyak 829 anak (91\%). Mayoritas pelaku tindak kejahatan didominasi oleh anak laki-laki sebanyak 2.627 anak (91\%) dan anak perempuan sebanyak 252 anak (9\%) (Tempo, 2014). Survei yang dilakukan oleh pihak pengamatan sekolah bahwa perilaku agresi fisik, verbal, serta perilaku agresi non-kekerasan (yaitu, perilaku ilegal seperti pencurian, mengutil , va), penggunaan zat (misalnya, bir, anggur, rokok, minuman keras, marijuana), (Farrell, 2018).

Perilaku agresi seperti menggunakan pesan teks untuk mengancam seseorang secara fisik; memanggil seseorang yang anda kenal nama-nama yang yang tidak sesuai dengan nama aslinya ketika di facebook atau snapchat; dan memasang komentar kasar tentang seseorang yang dikenal secara online merupakan tindakan agresi yang dapat dilakukan dan dialami melalui teknologi komunikasi elektronik. Pemicu umum dari perilaku agresi tersebut adalah ketika seseorang mengalami emosi marah. Perasaan marah dapat berlanjut pada keinginan untuk melampiaskannya dalam satu bentuk tertentu dan pada objek tertentu (Lemmer, 2015). Sa'diyah, (2017) mengemukakan perilaku agresi adalah tingkah laku yang diarahkan dengan tujuan menyakiti makhluk hidup lain. Sentana (2007) menjelaskan bahwa ciri-ciri dari perilaku agresi adalah pelakunya bertujuan untuk mencelakakan, menyakiti, merusak, dan merugikan orang lain baik secara verbal maupun non verbal.

Salah satu tugas generasi muda penerus bangsa yang masih duduk di bangku persekolahan adalah belajar. Bukan untuk bermain, bersenang-senang dan nongkrong dalam gerombolan bersama teman. Hal tersebut dapat menimbulkan masalah pada remaja seperti mudah terpengaruh dengan hal-hal negatif karena kenakalan remaja merupakan bagian dari diri remaja. Kenakalan remaja mampu menurunkan kualitas pendidikan sehingga merusak generasi bangsa. Salah satu kenakalan remaja adalah perilaku agresi yang dari tahun ke tahun semakin meningkat. Tingginya angka perilaku agresi pada siswa SMA dianggap sebagai fenomena yang biasa, namun bisa sangat meresahkan bahkan merugikan. Maka dari itu, perlu adanya perhatian khusus untuk menangani atau bahkan menyelesaikan masalah tentang perilaku agresi pada remaja (Fatima \& Khatoon. 2015). Seharunya remaja tidak melakukan hal-hal yang negatif dan melakukan kenakalan remaja agar tidak merusak pendidikan bangsa.

Myers (2012) menyatakan bahwa perilaku agresi merupakan suatu perilaku yang diniatkan untuk mendominasi atau berperilaku secara verbal maupun fisik bentuk perilaku yang diarahkan pada tujuan untuk menyakiti atau melukai orang lain. Hurlock (2011), masa remaja masa remaja tengah (15-18 tahun). Masa remaja pertengahan yang duduk di Sekolah Menengah Atas memiliki ciri-ciri: sangat membutuhkan teman, ia cenderung bersifat narsistik/kecintaan pada diri sendiri, 
berada dalam kondisi keresahan dan kebingungan, karena pertentangan yang terjadi dalam diri, berkenginanbesar mencoba segala hal yang belum diketahuinya, dan keinginan menjelajah ke alam sekitar yang lebih luas dalam kondisi keresahan dan kebingungan, karena pertentangan yang terjadi dalam diri, berkenginan besar mencoba.

Sesuai dengan penelitian yang dilakukan oleh John Dollard \& Neal Miller (dalam Sarwono, 2009) menunjukkan perilaku agresi muncul karena tidak tercapainya keinginan menyebabkan ketidaknyamanan yang menimbulkan adanya kemarahan kemudian berubah menjadi perilaku agresi. Dalam jurnal Khamim Zarkasih Putro apabila tugas pekembangan sosial ini tidak dapat dilakukan dengan baik, maka remaja akan mengalami kesulitan dalam kehidupan sosialnya serta tidak dapat menuntaskan tugas perkembangan untuk fase-fase berikutnya. Sebaliknya, manakala remaja dapat menjalankan tugas-tugas perkembangannya akan membawa akibat positif dalam kehidupan sosial fase-fase berikutnya, menyebabkan ketidakbahagiaan pada remaja, dan tidak mengalami kesulitan - kesulitan dalam menuntaskan tugas - tugas perkembangan berikutnya.

Berdasarkan penjelasan di atas terlihat bahwa perilaku agresi muncul karena kemarahan dan emosinya tidak stabil, seharusnya remaja mampu mengontol emosinya supaya ia mampu melewati fase-fase krisis pada tahap perkembangan, tentunya dibutukan self management yang baik dalam perkembangan remaja. Adapun aktor eksternal meliputi faktor keluarga, faktor sekolah dan faktor lingkungan. Faktorfaktor tersebut membuat perilaku individu akan lebih dipengaruhi emosi mendalam yang berkaitan dengan kondisi tertekan/stres yang juga akan memunculkan perasaan seperti marah yang merupakan produk dari reaksi stressful dengan lingkungan (Setiowati, 2017). Sedangkan faktor internal (dari dalam) maupun faktor eksternal (dari luar). Faktor internal tersebut meliputi rasa frustasi, gangguan pengamatan dan tanggapan remaja, gangguan berfikir, intelegency remaja, gangguan emosi remaja, serta yang terpenting dari faktor internal ini adalah self management, karena berkaitan dengan bagaimana individu mengendalikan emosi serta dorongan-dorongan dari dalam dirinya.

Menurut Edelson (1998) manajemen diri adalah istilah yang digunakan untuk menjelaskan proses mencapai kemandirian. Individu merupakan perpaduan antara intelektual, emosional, spiritual, dan fisik. Sehingga self management merupakan pengendalian diri terhadap pikiran, ucapan, dan perbuatan yang dilakukan, dan mendorong pada diri terhadap hal-hal yang tidak baik dan peningkatan perbuatan yang baik dan benar. Self management adalah sebuah proses merubah "totalitas diri" dari segi intelektual, emosional, spiritual, dan fisik agar apa yang kita inginkan tercapai. Siswa SMA dapat mengenali dan memahami dirinya atau potensi yang dimilikinya dan melakukan perubahan dalam berbagai aspek baik aspek intelektual, emosional, spiritual, dan fisik menuju ke arah yang lebih baik, serta mengelolanya dengan baik dapat menemukan peluang diri.

Goleman (2008) menjelaskan kecerdasan emosi (emotional intelligence) adalah kemampuan untuk mengenali perasaan diri sendiri dan perasaan orang lain, kemampuan memotivasi diri sendiri dan kemampuan mengelola emosi dengan baik pada diri sendiri dan dalam hubungan dengan orang lain. Apabila seseorang pandai 
menyesuaikan diri dengan suasana hati individu yang lain, orang tersebut akan memiliki tingkat emosionalitas yang baik dan akan lebih mudah menyesuaikan diri dalam pergaulan sosial serta lingkungannya. Kecerdasan emosional seseorang mampu menempatkan emosi secara tepat, memilah kepuasan dan mengatur suasana hati.

Dalam menjalankan perannya secara sosial, remaja seharusnya sudah mengetahui aturan dan norma yang berlaku di masyarakat. Sejalan dengan itu remaja seharusnya memiliki kecerdasan sosial yang lebih baik dalam berhubungan dengan teman sebaya dan lingkungan sosialnya. Dengan begitu, individu yang ingin berkembang akan berusaha untuk meregulasi dirinya semaksimal mungkin dalam mencapai tahap perkembangan yang diinginkannya. Sementara individu yang kurang mampu dalam meregulasi diri, lebih sulit mencapai kesuksesan. Charlton (2016) diperlukan adanya kesadaran diri dan pengelolaan diri (self management) yang baik dari mereka sendiri (remaja), agar mereka mampu mengendalikan emosi dan mengatur diri mereka sendiri, tidak berperilaku kasar, berbicara kotor atau berperilaku agresi. Self management adalah suatu prosedur dimana individu mengatur perilakunya sendiri. Trost (2015) mengartikan self management adalah teknik menata perilaku individu yang bertujuan untuk mengarahkan dan mengelola dirinya agar dapat mencapai kemandirian dan hidupnya berjalan dengan produktif. Strategi manajemen diri, dimana siswa menggunakan strategi manajemen diri kognitif dan perilaku yang terkait dengan partisipasi aktivitas fisik misalnya, penetapan tujuan dan penguatan diri yang positif.

Menurut Fitri, (2013) self management adalah strategi yang digunakan siswa untuk mengontrol faktor yang mempengaruhi proses belajar, yaitu strategi perilaku (manajemen waktu dan pengaturan) lingkungan fisik dan sosial, strategi motivasi menyusun tujuan dan meregulasi emosi, strategi belajar dan cara belajar. Ketika seorang siswa memiliki self management yang tinggi dalam belajar, siswa tersebut akan mampu mengatur dan mengelola dirinya dengan baik terutama dalam belajar (Nauli, 2014). Self management merupakan suatu kemampuan yang berkenaan dengan keadaan diri sendiri dan ketrampilan dimana individu mengarahkan pengubahan perilakunya sendiri untuk belajar dengan memanipulasi stimulus dan respon baik internal maupun eksternal. Suwardani (2014) mengartikan self management adalah bentuk perilaku individu yang bertujuan untuk mengarahkan dan mengelola dirinya agar dapat mencapai kemandirian dan hidupnya berjalan dengan produktif. Self management adalah suatu proses dimana individu mengarahkan perubahan tingkah lakunya sendiri (Cornier \& Nurius, 2003). Sehingga, pentingnya self management dalam perilaku agresi dapat memberikan dampak positif terhadap perilaku agresi pada siswa SMA.

Adapun perbedaan penelitian ini terhadap penelitian sebelumnya yaitu: penelitian ini menggunakan subjek siswa SMA yang berbeda tempat dengan penelitian sebelumnya. Penelitian ini menggunakan variabel self management yang mencakup aspek lebih luas.

Berdasarkan uraian di atas dapat disimpulkan bahwa perilaku agresi pada remaja sering mucul ketika remaja dalam keadaan emosi yang tidak stabil dan menyebabkan kemarahan. Penelitian tersebut penting dilakukan karenaa perilaku agresi akan semakin tinggi, dan akan berkembang pada persepsi siswa bahwa perilaku agresi merupakan perbuatan biasa-biasa saja. Dalam hal ini self management mampu 
mengatur dan mengelola keadaan diri sendiri terutama untuk self management dan perilaku agresi. Adapun rumusan masalah pada penelitian ini adalah apakah terdapat hubungan self management dengan perilaku agresi pada siswa SMA? Penelitian ini bertujuan untuk mengetahui hubungan self management dengan perilaku agresi pada siswa SMA. Manfaat teoritis dari penelitian ini adalah untuk pengembangan teori psikologi sosial dan psikologi pendidikan. Adapun manfaat praktis dari penelitian ini adalah untuk melakukan psikoedukasi mengenai self management dan perilaku agresi pada siswa SMA. Selanjutnya bagi pihak-pihak yang terkait, diharapkan penelitian ini dapat memberikan informasi terkait pentingnya self managememnt untuk kehidupan di masa depan.

\section{METODE}

Penelitian ini merupakan penelitian kuantitatif korelasional. Menurut Azwar (2010) penelitian korelasional bertujuan untuk mengetahui sejauh mana suatu variabel berkaitan dengan variasi pada variabel lain. Selain itu dapat memperoleh informasi mengenai hubunganan antar variabel yang terjadi, bukan mengenai ada tidaknya hubungan efek dari varibel lain. Menurut Azwar (2010) pendekatan kuantitatif adalah analisis pada data-data numerical (angka) yang kemudian akan diolah menggunakan metode statistik. Data kuantitatif adalah data yang berbentuk angka atau data kualitatif yang diangkakan atau skoring (Sugiyono, 2012).

Menurut Winarsunu (2009) populasi adalah seluruh individu yang akan diteliti dan kemudian setelah peneliti menentukan populasi, peneliti akan memperkecil menjadi sebuah sampel. Menurut Sugiyono (2017) sampel adalah sebagian dari jumlah dan karakteristik dari populasi tersebut. Sampel dari penelitian ini sebanyak $2175 \%$ dari jumlah populasi 450 siswa siswi SMA Negeri 1 Padangan Bojonegoro kelas X dan XI. Diambil menggunakan teknik stratified sampling yaitu menggunakan rumus slovin adalah suatu metode pengambilan sampel dimana populasi yang bersifat heterogen dibagi-bagi (strata) kemudian dari setiap strata dapat diambil sampel secara acak. Pengambilan data stara secara acak yang dimaksudkan 50\% kelas X dan 50\% kelas XI dari total populasi.

Pada penelitian ini terdapat dua variabel yaitu variabel bebas $(X)$ dan variabel terikat $(\mathrm{Y})$.Variabel bebas $(\mathrm{X})$ dalam penelitian ini adalah self management dan variabel terikat $(\mathrm{Y})$ dalam penelitian ini adalah perilaku agresi. Self management yang peneliti maksud kemampuan seseorang untuk mengontrol diri sendiri, yaitu dengan cara mengenali diri sendiri baik secara fisik,maupun psikologi termasuk emosinya. Instrument penelitian ini menggunakan skala self management disusun berdasar teori Trost \& Hutley (2015) ada dua aspek dalam self management yaitu: self management kognitif dan self management behavior. Skala ini berjumlah 14 item alat ukur akan diadaptasi oleh peneliti yang berdasar dua aspek dalam self management.

Perilaku agresi adalah perilaku seseorang untuk menyakiti orang lain yang dilakukan secara fisik maupun secara verbal. Seseorang yang melakukan tindakan perilaku agresi biasanya orang tersebut dalam keadaan marah apabila dalam keadaan marah emosi tidak terkontrol. Perilaku agresi berdampak pada kekerasan fisik seperti memukul, menendang, menampar, dll. Sedangkan perilaku agresi secara verbal seperti mencela, menghina termasuk mencela di media sosial.Instrumen penelitian perilaku 
agresi disusun berdasar teori (Little, Jones, Hendrich, \& Hawley, 2003). Perilaku agresi terdiri dari 17 item memiliki tiga aspek, yaitu: perilaku agresi relasional, perilaku agresi instrumental, perilaku agresi reakif. Kedua alat ukur tersebut akan dinilai pada skala likert 4 poin dengan item yang bersifat mendukung konsep (favorable) yang terdapat empat pilihan jawaban yaitu: Sering (S), Pernah (P), Jarang (J) dan Tidak Pernah (TP). Kemudian dirincikan dengan sering diberikan nilai 4, pernah nilai 3, jarang nilai 2 dan tidak pernah nilai 1.

Tabel 1. Indeks Validitas dan Reliabilitas Alat Ukur Penelitian

\begin{tabular}{ccccc}
\hline Alat Ukur & $\begin{array}{c}\text { Jumlah Item } \\
\text { yang Diujikan }\end{array}$ & $\begin{array}{c}\text { Jumlah Item } \\
\text { Valid }\end{array}$ & $\begin{array}{c}\text { Indeks } \\
\text { Validitas }\end{array}$ & $\begin{array}{c}\text { Indeks } \\
\text { Reliabilitas }\end{array}$ \\
\hline Self Management & 14 item & 8 item & $0,331-0,652$ & 0,735 \\
Perilaku Agresi & 17 item & 12 item & $0,336-0,705$ & 0,831 \\
\hline
\end{tabular}

Berdasarkan uji validitas dan reliabilitas dari hasil try out yang telah dilakukan sebanyak 60 subjek anak SMA kelas X dan XI di Kota Malang dan Bojonegoro dilakukan secara online menggunakan program google formulir, diperoleh alat ukur self management dari 14 item, terdapat 6 item yang tidak valid sehingga tersisa 8 item valid dari hasil uji coba. Indeks validitas alat ukur self management berkisar antara 0,331 - 0,652 dengan indeks reliabilitas sebesar 0,735. Sedangkan alat ukur perilaku agresi berjumlah 17 item, terdapat 5 item yang tidak valid sehingga tersisa 12 item valid. Serta memiliki indeks validitas berkisar antara 0,336 - 0,705 dengan nilai reliabilitas 0,831 .

Penelitian yang akan dilakukan terdiri dari tiga prosedur yaitu tahap persiapan, tahap pelaksanaan dan tahap analisa data. Tahap persiapan yaitu tahap awal dari penelitian. Peneliti menentukan variabel penelitian. Selanjutnya peneliti memahami kajian teoritk dari variabel tersebut. Setelah itu melakukan proses adaptasi skala dan melakukan uji coba skala (try out) bertujuan untuk mendapatkan nilai validitas dan reliabilitas. Tryout dilakukan di kota Malang dan Bojonegoro dilakukan berkisar 2 minggu pada tanggal 1 Mei 2019 hingga 14 Mei 2019 try out diberikan kepada subjek pada siswa-siswi SMA kelas X dan XI, usia 16-18 tahun yang dilakukan secara online menggunakan program google formulir dimana subjek diminta untuk mengisi secara online sesuai tahapan yang telah peneliti tentukan. Selanjutnya peneliti melakukan analisa SPSS 22 untuk mengetahui validitas dan reliabilitas.

Tahap pelaksanaan, yaitu tahap dimana peneliti menyebarkan skala pada siswa SMA yang memenuhi persyaratan sesuai kriteria sampel. Sebelum alat ukur (skala) akan disebarkan oleh peneliti, peneliti membuat surat perizinan dari pihak fakultas kemudiam menyerahkan berkas tersebut kepada kepala sekolah SMA Negeri 1 Padangan Bojonegoro, Jawa Timur yang akan peneliti lakukan. Skala yang disebar sebanyak 217 kuesioner. Penyebaran skala dilakukan pada tanggal 20 Mei 2019 - 1 Juni 2019.

Tahap terakhir, yaitu tahap analisa data pada analisa data meliputi penginputan dan pengolahan data dari kuesioner yang telah disebar, data-data tersebut kemudian diolah menggunakan teknik analisis uji korelasi product moment untuk mengetahui korelasi antar dua variabel yang diteliti, serta untuk melakukan analisis dan 
interpretasi data, dibantu dengan menggunakan aplikasi IBM SPSS for windows version 22. Kemudian data yang didapatkan akan dijelaskan berdasarkan teori serta penjelasan tersebut dapat disimpulkan oleh peneliti.

HASIL

Tabel 2. Perhitungan T-Score Self Managemenet (X)

\begin{tabular}{cccccc}
\hline Kategori & Interval & Frekuensi & Persentase & SD & Mean \\
\hline Tinggi & T-skor $>50$ & 109 & $50,2 \%$ & & \multirow{2}{*}{3,9} \\
\cline { 1 - 3 } Rendah & T-skor $\leq 50$ & 108 & $49,8 \%$ & & 21,4 \\
\hline \multicolumn{7}{c}{ Total } & $\mathbf{2 1 7}$ & $\mathbf{1 0 0} \%$ & & \\
\hline
\end{tabular}

Dilihat pada tabel 2, diketahui bahwa jumlah subjek yang memiliki katergori tinggi pada self management sebanyak 109 atau sebesar 50,2\% dan jumlah subjek dengan kategori rendah sebanyak 108 atau sebesar 49,7\%. Sehingga dapat diketahui bahwa jumlah subjek yang berkategori tinggi pada self management lebih banyak dibandingkan dengan jumlah subjek yang berkategori rendah.

Tabel 3. Perhitungan T-Score Perilaku Agresi (Y)

\begin{tabular}{|c|c|c|c|c|c|}
\hline Kategori & Interval & Frekuensi & Persentase & SD & Mean \\
\hline Tinggi & T-skor $>50$ & 103 & $47,5 \%$ & \multirow{2}{*}{4,9} & \multirow{3}{*}{19,08} \\
\hline Rendah & T-skor $\leq 50$ & 114 & $52,5 \%$ & & \\
\hline & Total & 217 & $100 \%$ & & \\
\hline
\end{tabular}

Pada tabel 3. Dapat dilihat bahwa jumlah subjek yang memiliki kategori tinggi dari perilaku agresi sebanyak 103 atau sebesar 47,5\%. Sedangkan jumlah subjek yang berkategori rendah sebanyak 114 atau sebesar 52,5\%. Sehingga dapat diketahui bahwa jumlah subjek yang berkategori tinggi lebih sedikit daripada subjek yang berkategori rendah.

Tabel 4. Kategorisasi Berdasarkan Jenis Kelamin

\begin{tabular}{lcccc}
\hline \multicolumn{1}{c}{ Kategori } & \multicolumn{2}{c}{ Self Management } & \multicolumn{2}{c}{ Perilaku Agresi } \\
\hline Laki-laki & Perempuan & Laki-laki & Perempuan \\
\hline Tinggi & $49 \%$ & $51 \%$ & $49 \%$ & $43 \%$ \\
Rendah & $51 \%$ & $49 \%$ & $51 \%$ & $57 \%$ \\
\hline Total & $100 \%$ & $100 \%$ & $100 \%$ & $100 \%$ \\
\hline
\end{tabular}

Dilihat dari tabel 4. Dapat diketahui bahwa persentase self management dan perilaku agresi pada siswa laki-laki dan perempuan memiliki perbedaan. Nilai persentase self management pada siswa perempuan lebih tinggi daripada nilai persentase pada siswa laki-laki. Sedangkan pada perilaku agresi terdapat pula perbedaan nilai persentase yaitu pada siswa laki-laki nilai persentasenya lebih tinggi dibandingkan perempuan. 
Tabel 5. Hasil Analisa Korelasi Self Management dan Perilaku Agresi

\begin{tabular}{lc}
\hline \multicolumn{1}{c}{ Koefisien Korelasi } & Indeks Analisis \\
\hline Koefisien Korelasi $(\mathrm{r})$ & $-0,122$ \\
Koefisien Determinasi $\left(\mathrm{r}^{2}\right)$ & 0,015 \\
Nilai Signifikansi $(p)$ & 0,037 \\
\hline
\end{tabular}

Dari uji korelasi yang dilakukan dengan analisa korelasi product moment. Diperoleh koefisien korelasi (r) sebesar -0,122 dengan signifikan (p) sebesar 0,037< 0,05 . Berdasarkan hasil tersebut menunjukkan bahwa terdapat hubungan negatif antara self management dengan perilaku agresi. Artinya semakin tinggi self management siswa SMA maka semakin rendah perilaku agresi pada siswa SMA, begitu juga sebaliknya semakin rendah self management siswa SMA maka semakin tinggi perilaku agresi pada siswa SMA. Sehingga hipotesis yang telah diajukan peneliti diterima. Selanjutnya diperoleh nilai koefisien determinasi (r2) sebesar 0,015. Hal ini diartikan bahwa self management memiliki sumbangan efektif dari perilaku agresi pada siswa SMA sebesar 1,5\%, sedangkan sebesar 98,5\% dipengaruhi oleh faktor lain.

\section{DISKUSI}

Berdasarkan penelitian yang telah dilakukan menunjukkan bahwa terdapat hubungan negatif yang signifikan antara self management dengan perilaku agresi pada siswa SMA Negeri 1 Padangan Bojonegoro. Hal ini didasarkan dari hasil analisis menggunakan uji korelasi product moment dengan nilai koefisien korelasi (r) sebesar 0,122 dengan nilai $p$ sebesar $0,037<0,05$. Hal ini menunjukkan bahwa semakin tinggi self management yang dimiliki siswa maka semakin rendah perilaku agresi siswa SMA. Sebaliknya, semakin rendah self management yang dimiliki siswa SMA, maka semakin tinggi perilaku agresi siswa.

Self management memiliki hubungan atau korelasi ke arah negatif dengan perilaku agresi, seperti dengan hipotesis yang peneliti sebutkan sebelumnya. Self management merupakan proses pengubahan tingkah laku yang dilakukan dengan satu atau lebih strategi. Melalui pengelolaan tingkah laku baik dapat dilakukan secara internal dan eksternal, sehingga perubahan perilaku menjadi syarat penting untuk menumbuhkan motivasi individu. Oleh sebab itu, self management menjadi hal yang sangat penting bagi individu. (Southall \& Gast, 2011). Hal ini berbanding terbalik dengan perilaku agresi merupakan bentuk perilaku negatif yang timbul karena adanya pengaruh terutama pengaruh dari lingkungan yang sering mengakibatkan dampak yang negatif. Perilaku agresi dapat berupa fisik maupun verbal sehingga perilaku agresi dapat membahayakan orang lain (Retnowulan, 2013).

Self management berhubungan dengan kesadaran diri dan keterampilan untuk mengatur keadaan sekitarnya yang mempengaruhi tingkah laku individu (Lutfi \& Fauzan, 1992). Penelitian (Trevino, Kamps \& Wills,2015) bahwa teknik perubahan perilaku self management merupakan salah satu dari penerapan teori modifikasi perilaku dan merupakan gabungan teori behavioristik dan teori kognitif sosial. Sesuai dengan seperti hasil penelitian dari Susanto (2006) yang menyimpulkan bahwa keberhasilan seseorang dalam menjalani sesuatu pencapaian prestasi baik dalam 
pendidikan maupun dalam bidang lainnya tidak ditentukan oleh IQ namun salah satunya adalah kemampuan manajemen diri.

Suci (2008) menyimpulkan bahwa dengan kemampuan manajemen diri maka seseorang akan dapat mengembangkan dan mengatur rencana sehingga tujuan yang diinginkannya dapat tercapai. Hal ini dapat dipahami karena untuk meraih suatu perilaku memerlukan adanya suatu dorongan untuk mengarahkan dan mencapai tujuan tertentu sesuai standarnya yaitu perilaku yang lebih baik dari pada orang lain (Schimtz \& Wiese, 2006). Uno (2007) menyatakan bahwa individu yang memiliki self management yang tinggi akan cenderung memiliki tingkat kepercayaan diri yang tinggi, mempunyai tanggungjawab, selalu berusaha mencapai hasil yang baik, aktif dalam kehidupan sosial.

Berdasarkan penelitian yang telah dilakukan pada 217 subjek diketahui bahwa sebanyak 50,2\% siswa memiliki skor self management yang tinggi, sedangkan siswa yang memilki self management rendah sebanyak 49.8\%. Kemudian sebanyak 52,5\% siswa memiliki skor perilaku agresi berkategori lebih rendah, sedangkan sebanyak 47,5\% siswa memiliki skor perilaku agresi tinggi. Hal ini sesuai dengan hasil penelitian yang dilakukan (Yuan dan Che, 2012) di SDN Brenggolo 1 Kabupaten Kediri, bahwa terdapat penurunan pada skor kecenderungan perilaku agresi, sehingga dapat diartikan bahwa penggunaan strategi self management ini memiliki peran penting pada perilaku agresi siswa SMA.

Menurut Hall (Sarwono, 2011) masa remaja 16-18 tahun merupakan masa "sturm und drang" masa penuh emosi dan, yang muncul karena adanya pertentangan nilainilai. Emosi ini akan menyulitkan bagi remaja tersebut atau orang tua. Namun emosi yang ini juga bermanfaat bagi remaja dalam upaya menemukan identitas diri.

Menurut Amin (2017) tujuan dari strategi self management adalah agar individu dapat menempatkan diri dalam situasi yang menghambat tingkah laku yang mereka hendak hilangkan dan belajar untuk mencegah timbulnya perilaku atau masalah yang tidak dikehendaki. Dalam arti individu dapat mengelola pikiran, perasaan dan perbuatan mereka sehingga mendorong peningkatan hal-hal yang baik dan benar. Beberapa penelitian terdahulu yang menggunakan strategi self management menunjukkan bahwa strategi ini efektif dalam mengurangi masalah perilaku, seperti perilaku agresi dan memperkuat berbagai perilaku positif.

Berdasarkan analisa yang telah dilakukan hasil koefisien determinan $\left(\mathrm{r}^{2}\right)$ sebesar 0,015 atau 1,5\%. Berarti bahwa variabel self management memiliki sumbangan sebesar 1,5\% terhadap perilaku agresi pada siswa SMA. Sehingga sisanya sebesar 98,5\% faktor lain yang mempengaruhi perilaku agresi pada siswa SMA. Faktor lain terdapat dalam penelitian Arif, (2017) diantaranya faktor tersebut meliputi: frustasi, gangguan pengamatan dan tanggapan remaja, gangguan berfikir dan intelegency remaja, serta gangguan perasaan/emosional remaja.

Kelemahan dari penelitian ini adalah kurang luasnya aspek yang digunakan dalam skala self management dimana dalam skala ini yang digunakan hanya aspek kognitif dan behavior seharunya terdapat tiga aspek kognitif, behavior dan emosi. Selanjutnya cara pengambilan data dengan kuisioner yang kurang efisien hal tersebut dikarenakan terdapat hasil dari jawaban subjek yang bias. 


\section{SIMPULAN DAN IMPLIKASI}

Berdasarkan hasil penelitian yang dilakukan dapat disimpulkan bahwa hipotesis diterima yang berarti bahwa ada hubungan negatif yang signifikan antara self management dengan perilaku agresi pada siswa SMA. Hal ini berarti semakin tinggi self management maka semakin rendah perilaku agresi pada siswa, Sebaliknya semakin rendah self management maka semakin tinggi perilaku agresi pada siswa SMA.

Adapun implikasi dari penelitian ini adalah : Mengingat bahwa perilaku agresi adalah contoh perilaku yang tidak baik bagi manusia, dan akan merugikan diri sendiri atau orang lain, diharapkan siswa tidak melakukan tindakan atau perilaku agresi di lingkungan sekolah atau di lingkungan rumah. Bagi orang tua dan guru dan pihak sekolah, diharapkan memberikan pengarahan baik di lingkungan sekolah atau dirumah, bahwa perilaku agresi tidak baik dilakukan. Bagi peneliti selanjutnya, diharapkan melakukan penelitian menggunakan skala yang sesuai dengan cakupan aspek meliputi (kognitif, behavior, emosi dan afeksi). Selain itu diharapkan mampu memberikan perbedaan faktor lain misalkan intelegensi, perbedaan dari laki-laki dan perempuan serta pebedaan budaya yang menjadi pengaruh dari perilaku agresi.

\section{REFERENSI}

Alfabeta, R.I. (2016). Penerapan strategi pengelolaan diri (self-management) untuk mengurangi kecanduan media sosial pada siswa kelas xi sman 1 pandaan. Jurnal BK UNESA, 6(2).

Álvarez G.D., Barreiro C.A., Núñez, J. C., \& Dobarro, A. (2016). Validity and reliability of the cyber-aggression questionnaire for adolescents (CYBA). The European Journal of Psychology Applied to Legal Context, 8(2), 69-77.

Amalia, A., Astuti, I., \& Wicaksono, L. (2016). Studi kasus tentang siswa yang berperilaku agresif pada kelas x sma santun untan pontianak. Jurnal Pendidikan dan Pembelajaran, $7(2)$.

Amin, Maswardi \& Muhammad (2016). Membangun pribadi berbudi pekerti.Yogyakarta: Calpulis

Anderson, C.A. (2000).Violent video games increase aggression and violence. Jurnal The Impact Of Interactive Violence On Children.

Annisavitry, Y., \& Budiani, M.S. (2017). Hubungan antara kematangan emosi dengan agresivitas pada remaja. Jurnal Penelitian Psikologi, 4(1)

Azevedo, J.C., Pais, R.J.L., Coelho, R.., \& Figueiredo, B.M. (2018). Validation of the portuguese version of impulsive-premeditated aggression scale in an inmate population. Frontiers in psychiatry, 9, 10.

Azwar, S. (2010). Metode penelitian. Yogyakarta: Pustaka Pelajar.

Baron, R.A., \& Byrne. D. (2012). Psikologi sosial. jilid 2. Jakarta: Erlangga.

Berkowitz, L. (2003). Aggression: Its causes, consequences and control . New York.

Buss, A.H \& Perry, M. (1992). The aggression questionnaire. Journal of personality and social psychology. The American Psychological

Association, Inc.Card, N.A., Isaacs, J., \& Hodges, E.V.E. (2008).Multiple contextual levels of risk for peer victim-ization: A review with recommendations for pre-vention and intervention. In T. W. Miller (Ed.), School violence and primary prevention (pp. 125-153). New York, NY: Springer.

Charlton, C.T. (2016). Effects of a self-management procedure using student feedback on staff members' use of praise in an out-of-school time program. 
Cormier, S \& Nurius, S.P. (2003). Interviewing and change strategies for helpers.brooks/cole. USA.

Da C.M., Gaspar, M.F., \& Barros, L. (2017). Training camp: effects of an educational program for self-management, on adolescents with spina bifida. Academy of Strategic Management Journal, 16(2).

Dayakisni Tri, \& Hudaniah (2009). Psikologi sosial. Edisi keempat. Malang: UMM Press

Dirks, M.A., Cuttini, L.A., Mott, A., \& Henry, D.B. (2017). Associations between victimization and adolescents' self-reported responses to peer provocation are moderated by peerreported aggressiveness. Journal of research on adolescence, 27(2), 436-451.

Edelson, S.M. (1998). Self management. Tersedia (online): www.autism.org/self- manage.html (02 Oktober 2012).

Farrell, A.D., Thompson, E.L., Mehari, K.R., Sullivan, T.N., \& Goncy, E.A. (2018). Assessment of in-person and cyber aggression and victimization, substance use, and delinquent behavior during early adolescence. Assessment.

Fatima, S., \& Khatoon, S. (2015). Causes of students' aggressive behavior at secondary school level. Journal of Literature, Languages and Linguistics, 11, 49-65.

Fauzan, Lutfi. (1992). Pengubahan kebiasaan belajar siswa sma dengan siasat kelola diri. malang: Tesis S2 FPS IKIP Malang

Finigan, C.N.M., Gielen, A., Haynie, D.L., \& Cheng, T.L. (2016). Youth violence: how gender matters in aggression among urban early adolescents. Journal of Interpersonal Violence, 31(19), 3257-3281.

Fitri, A.D. (2013). Penerapan strategi pengelolaan diri (self-management) untuk mengurangi perilaku konsumtif pada siswa kelas $\mathrm{x}-11$ sman 15 surabaya. Jurnal Bk Unesa, 1(1).

Hergenhahn, B.R \& Olson, M.H, (2008). Theories of learning (teori belajar). Jakarta : Kencana Prenada Media Group.

Hurlock, E.B. (2011). Psikologi perkembangan : suatu pendekatan sepanjang rentang kehidupan. Jakarta : Erlangga.

John, W.S. (2007). Perkembangan anak. Jilid 1 Edisi kesebelas. Jakarta : PT. Erlangga.

Kisokanth, G., Prathapan, S., Indrakumar, J. \& Joseph, J. (2013). Factors influencing selfmanagement of diabetes mellitus: A Review Article. Journal of Diabetology,

Kirsh, S.J. (2006). Children, adolescents, and media violence: a critical look at the research. USA: Sage Publicatio, Inc.

Koswara, E. (1988). Agresi manusia. Bandung:PT. Eresco.

Lemmer, G., Gollwitzer, M., \& Banse, R. (2015). On the psychometric properties of the aggressiveness-iat for children and adolescents. Aggressive behavior, 41(1), 84-95.

Lickley, R.A., \& Sebastian, C.L. (2018). The neural basis of reactive aggression and its development in adolescence. Psychology, Crime \& Law, 24(3), 313-333.

Little, T., Jones, S., Henrich, C., \& Hawley, P. (2003). Disentangling the "whys" from the "whats" of aggressive behaviour. International Journal of Behavioral Development , 27, 122-133.

Lukmansyah, D \& Andini, P. (2012). Data tawuran pelajar selama 2010-2012. Diunduh tanggal 2 januari 2015 dari http://video.tvOneNews.tv/arsip.

Nauli, F.A. (2014). Faktor-Faktor yang mempengaruhi perilaku agresif remaja di smk negeri 2 pekanbaru. Jurnal Online Mahasiswa (JOM) Bidang Ilmu Keperawatan, 1(2), 1-9.

Monks, F.j (2004). Psikologi permkembangan pengantar dalam berbagai bagiannya.Yogyakarta : Universita Gajah Mada

Myers, D.G. (2002). Psikologi sosial. Jakarta : Erlaangga

Orpinas, P., \& Frankowski, R. (2001). The aggression scale: a self-report measure of aggressive behavior for young adolescents. The Journal of Early Adolescence, 21(1), 50-67. 
Retnowulan, D. A \& Warsito, H. (2013). Penerapan strategi pengelolaan diri (selfmanagement) untuk mengurangi kenakalan remaja korban broken home. Jurnal BK Unesa. Volume 03 Nomor 01. 335-340.

Rinanda. (2006). Manajemen diri. Bandung: Liberty.

Routt, G., \& Anderson, L. (2018). Adolescent aggression dolescent violence to wards parents. Journal of aggression, maltreatment \& trauma, 20, 1-19

Sa'diyah, H., Chotim, M., \& Triningtyas, D.A. (2017). Penerapan teknik self management untuk mereduksi agresifitas remaja. counsellia: Jurnal Bimbingan dan Konseling, 6(2), 67-78.

Saelens BE., Gehrman CA., Sallis JF. (2000). Penggunaan strategi manajemen diri dalam intervensi kognitif-perilaku 2 tahun untuk mempromosikan aktivitas fisik. Behavior Therapy

Santrock J.W .(2007). Perkembangan anak. Jilid 1 Edisi 11. Jakarta : Erlangga.

Santrock, J.W. (2011). Perkembangan anak. Jakarta : Erlangga.

Sarwono, S.W., \& Meinarno, E.A. (2009). Psikologi sosial. Jakarta: Salemba Humanika.

Sarwono. (2011). Psikologi remaja. Jakarta: Rajawali Pers

Schmitz, B., \& Wiese, B. S., (2006) New prspectives for the evaluation of training sessions in self regulated learning:Time series analyses of diary data contemporary Educational Psychology Vol.6231, no. 1, 6496

Sentana, M.A., \& Kumala, I.D. (2017). Agresivitas dan kontrol diri pada remaja di banda aceh. Jurnal Sains Psikologi, 6(2), 51-55.

Setiowati, E.A., Suprihatin, T., \& Rohmatun, R. (2017). Gambaran agresivitas anak dan remaja di area beresiko. Prosiding Temu Ilmiah Nasional X Ikatan Psikologi Perkembangan Indonesia, 1.

Southall, C. M., \& Gast, D. L. (2011). Self-management procedures: A comparisonacross the autism spectrum. Education and training in Autism anddevelopmental disabilities, 155171.

Shelton, D., Sampl, S., Kesten, K. L.,Zhang, W., \& Trestman, R. L.(2017). Treatment of impulsive aggression in correctional settings. Behavioral Sciences and the Law,27: 787-800.

Stewart Trost G (2004). Pendidikan jasmani sekolah di era pasca laporan: analisis dari kesehatan masyarakat. J Teach Phys Educ. Sugiyono, (2012). Metode penelitian kuantitatif kualitatif . Bandung: Alfabeta.

Suci, E (2009). Gambaran perilaku jajan murid sekolah dasar di Jakarta.Jakarta: Psikobuana. Vol. 1. No. 1.2938.

Sugiyono. (2017). Metode penelitian kuantitatif, kualitatif, dan R\&D. Bandung: Alfabeta

Suryabrata S (1984). Psikologi pendidikan. Jakarta : Rajawali

Suwardani, N.K.P., Dharsana, I.K., \& Suranata, K. (2014). Penerapan konseling behavioral dengan teknik self management untuk meningkatkan konsep diri siswa kelas viii b3 smp negeri 4 singaraja. Jurnal Ilmiah Bimbingan Konseling Undiksha, 2(1).

Thalib, S.B. (2010). Psikologi pendidikan berbasis analisis empiris Aplikatif. Jakarta: Kencana Media Group.

Trevino M, S. I., Kamps, D., \& Wills, H. (2015). A group contingency plus selfmanagement intervention targeting at-risk secondary students' class-work and active engagement. Remedial and Special Education, 36(6), 347-360.

Trost, S.G., \& Hutley, J. (2015). Use of physical activity self-management strategies by high school students. Pediatric exercise science, 27(1), 168-174.

Uno, H.B. (2007). Model pembelajaran menciptakan proses belajar mengajar yang kreatif dan efektif. Jakarta: Bumi Aksara

Winarsunu,T. (2009). Statistik dalam penelitian psikologi dan pendidikan. Malang: UM 